\title{
THE SILENT CHILD: REFORM PEDAGOGY, THE SELF AND THE PROBLEMATIZATION OF SHYNESS IN THE CLASSROOM*
}

\author{
El niño silencioso: la Escuela Nueva, el yo y la problematización \\ de la timidez en el aula
}

\section{Pieter Verstraete ${ }^{\alpha}$}

Reception date: 14/04/2021 • Acceptation date: 08/09/2021

\begin{abstract}
In the existing historical and sociological studies devoted to shyness scholars have identified the second half of the Twentieth century as an important period in which shy feelings have become a problem for Western societies. On the basis of the work of the American cultural historian Warren Susman, and especially his ideas about the move from a character society towards a personality society, it is argued that the turn of the nineteenth century also played an important role in the emergence of negative interpretation of being and acting shy. In this article Susman's attention for what happened at the start of the twentieth century is being taken up by examining the ideas about timidity in the work of one of the most important reform educators at that time, namely Maria Montessori. Montessori's ideas are being contextualized by referring to the more encompassing culture of personality and the self that paralleled the progressive era in education. By contraposing Montessori's ideas to an eighteenth-century ego-document written by someone who identified himself as a shy person we'd like to plea for a nuanced account with regard to the history of the problematization of shyness in general and shy children in particular.
\end{abstract}

Keywords: Shyness; Reform pedagogy; History; The self.

\footnotetext{
" This article is an extended and thoroughly revised version of the concise chapter submitted to and published in the Liber Amicorum for the Dutch historian of education Jeroen Dekker: Verstraete, Pieter, "Het verlegen kind. Een pedagogische kijk op de geschiedenis van emoties", en Images of education: cultuuroverdracht in historisch perspectief, eds. Hilda Amsing, Nelleke Bakker, Minneke van Essen \& Sanne Parlevliet (Groningen: Uitgeverij Passage, 2018). 235-247.

${ }^{\alpha}$ Research Unit Education, Culture and Society, Faculty of Psychology and Educational Research, KU Leuven, Andreas Vesaliusstraat 2, 3000 Leuven, Belgium. Pieter.verstraete@kuleuven.be (D) https:// orcid.org/0000-0002-1482-3687
}

How to cite this article: Verstraete, Pieter. "The silent child: reform pedagogy, the self and the problematization of shyness in the classroom". Historia y Memoria de la Educación 15 (2022): 297-321 
Resumen. En los estudios históricos y sociológicos existentes dedicados a la timidez, los estudiosos han identificado la segunda mitad del siglo XX como un periodo importante en el que los sentimientos de timidez convirtieron en un problema para las sociedades occidentales. Sobre la base de la obra del historiador cultural estadounidense Warren Susman, y especialmente de sus ideas sobre el paso de una sociedad del carácter a una sociedad de la personalidad, el final del siglo XIX también desempeñó un papel importante en la aparición de la interpretación negativa del hecho de ser tímido y actuar con timidez. En este artículo se retoma la atención de Susman por lo ocurrido a principios del siglo XX, examinando las ideas sobre la timidez de una de las educadoras reformistas más importantes de la época, a saber, María Montessori. Las ideas de Montessori se contextualizan refiriéndose a la cultura más amplia de la personalidad y el yo que fue paralela a la era progresista en la educación. Al contraponer las ideas de Montessori a un documento sobre el yo del siglo XVIII escrito por alguien que se identificaba a sí mismo como una persona tímida, nos gustaría abogar por un relato matizado con respecto a la historia de la problematización de la timidez en general y de los niños tímidos en particular.

Palabras clave: Timidez; Escuela Nueva; Historia; El yo.

\section{A PERSONAL ANECDOTE AS WAY OF INTRODUCTION}

This article is based upon personal experience. A few years ago, our daughter came home from kindergarten. In her school bag was a note from the teacher. Children often come home with a plastic folder containing school fees or information sheets. In itself, this is not unusual. This time, however, the content of the note, which the teacher had put in the folder, was just that. The note informed us that our six-year-old daughter would be from the next day participating in weekly meetings involved with assertiveness and well-being. The kindergarten department had decided, in consultation with the kindergarten teachers, to implement a specific curriculum for children who felt that they had difficulty in expressing their feelings. That is to say, the Magic Forest. ${ }^{1}$

\footnotetext{
1 The Magic Forest is a methodology which focuses upon the socio-emotional development of kindergarten children. It was developed between 2010 and 2012 in cooperation with the Child Psychiatry Service of the UZ Leuven (under the direction of Prof. Peter Adriaensens) and the non-profit association, $G a$ voor Geluk: Catherine Malfait \& Niki Jeannin, Emoties in de kleuterklas. Oefenen met de methode van "Het Toverbos" (Tielt: Lannoo Campus, 2014).
} 
Of course, there is nothing wrong with schools making an effort to make kindergarten and primary school children feel good about themselves. Quite the contrary. What we as parents found difficult was the manner of communication, the tone of the letter and especially the implicit value judgements which it contained. First of all, our annoyance had to do with the fact that the teacher had never let us know that she was worried about our daughter. Secondly, the content of the letter did not really match how we perceived our daughter. We knew, of course, that she was not a forward, outgoing child. But to infer from this the need for emotional remedial treatment seemed to us to be going one step too far. However, what shocked us most was what was said in the concluding paragraph of the letter. Just like the teachers and the department, it was stated that we, as parents, had the best interests of our child at heart and hoped that she would make a positive contribution to society in the future. What continually reverberated through the letter was the idea that you are only fully human if you go through life in an extrovert manner; that you only really count in our society if you don't let yourself be told off; that you can only make a contribution to society if you are an open book and always have a sharp tongue. Reticence, silence, introversion... and shyness were presented in the letter as character traits which complicate a person's life and are best updated through psychologically inspired curricula.

That school has become a place where normalising and disciplining influences are exerted upon children is not a new finding. Since the 1960s, numerous historical educators and other researchers have worked to uncover the specific power processes at work in school and other educational contexts. Inspired by this specific view of the educational past and present, some authors have also ventured to undertake a critical analysis of the diverse roles which emotions play within these power processes. Noteworthy in this context are the analyses by Megan Boler, Peter Stearns and Noah Sobe, among others. These studies clearly show that emotions are not neutral and purely biological phenomena, but that they are culturally constructed and are used in very different ways to achieve or counteract the educational goals which one has in mind. ${ }^{2}$

\footnotetext{
${ }^{2}$ Megan Boler, Feeling power: Emotions and education (New York: Routledge, 2004); Peter Stearns and Clio Stearns, "American schools and the uses of shame: an ambiguous history". History of
} 
Inspired by the anecdote described above, in this contribution to the special issue of the journal Historia y Memoria de la Educación with respect to health and education, I would like to make a contribution to the existing insights regarding the role of emotions in the history of parenting and education. In particular, I will focus upon the emotion of shyness and how reform pedagogics have contributed to the problematisation of feeling shy. ${ }^{3}$ Health in this article is accordingly not only seen as a physical condition. In the course of Western history, the human psyche, too, was increasingly expected to mirror a healthy state, and, in the course of the 19th and 20th centuries, feeling shy seemed to be less and less a part of it.

In the first instance, I will provide a brief overview of the existing historical studies relating to the emotion of shyness. From this overview it will become clear that the early 20th century period is considered by several authors to be a turning point. The question which is central to this article is whether reform pedagogics, and in particular the work of Montessori, can be linked to the increased tendency to present shyness as an abnormal state of mind. Although in this article I will mainly discuss Montessori's attitude to shyness, I would also like to confront the reader with an eighteenth-century autobiographical text from a 40-year-old man who described himself as shy. I will use this autobiographical source to undermine the idea that shyness only became a problem in the 20th century.

\section{SEARCHING FOR HISTORICAL TRACES OF SHYNESS}

Writing a history of shyness; this seems to be an impossible task. Firstly, there is the idea that emotions such as shyness are essentialist phenomena; ${ }^{4}$ phenomena which are linked to and caused by neurobiological processes and therefore produced and experienced in an unchanging way over time. The implicit anti-historical undertone of this

Education 46, no. 1 (2017): 58-75; Noah Sobe, "Researching emotion and affect in the history of education". History of education 41, no. 5 (2012): 689-95.

3 There is considerable debate as to whether shyness should be considered a personality trait or an emotion. In this paper, in line with the existing historical studies, we have opted to consider shyness as an emotion.

${ }^{4}$ A worthwhile introduction to the nature-nurture issue applied to emotions can be found in Peter Toohey, Verveling: een boeiende geschiedenis (Amsterdam: Ambo/Contact, 2012). 
view has been thoroughly questioned since the rise, among other things, of the history of emotions in the 1980s. ${ }^{5}$ Alongside psychological sub-disciplines such as social psychology, this branch of history focused mainly upon a social constructivist interpretation of emotions. Emotions are not understood here as a set of experiences which remain the same over time. Feelings are rather seen as social constructs to which meanings are attributed, which vary from time to time and from geographical context to geographical context.

In addition to this theoretical discussion, there is a second important element which complicates the writing of a history of shyness, namely the ephemeral and often paradoxical nature of shyness itself. Or, as Joe Moran puts it in his book Shrinking Violets: The Secret Life of Shyness: "the nebulous nature of shyness" ${ }^{6}$ Shyness is indeed a difficult emotion to grasp. The word shyness cannot be easily distinguished from other words which more or less refer to the same emotional state, but at the same time differ from it, such as "timidity", "bashfulness", "timorousness", "apprehensiveness", etc. If these subtle verbal nuances make it difficult to trace the past of shyness, it should be added that what characterises shyness - such as blushing, clammy hands, palpitations and stuttering - is extremely volatile and shy people are much less likely than others to leave traces behind them.

Despite these theoretical and methodological difficulties, a number of authors have recently ventured into a history of shyness. ${ }^{7}$ For most of these authors, this audacity has not only to do with the fact that you are embarking on a historical journey where you do not know in advance whether, and if so, what source material you will encounter. That audacity also has to do with the critical attitude adopted during that journey. Many of the existing historical overviews focus upon the influence of

\footnotetext{
${ }_{5}^{5}$ Please see for example Quentin Deluermoz, Emmanuel Fureix, and Hervé Mazurel, "Écrire l'histoire des émotions: de l'objet à la catégorie d'analyse". Revue d'histoire du XIXe siècle. Société d'histoire de la révolution de 1848 et des révolutions du XIXe siècle 47 (2013): 155-89; Jan Plamper, Geschichte und Gefühl: Grundlagen der Emotionsgeschichte (München: Siedler Verlag, 2012).

6 Joe Moran, Shrinking Violets: The Secret Life of Shyness (London: Profile Books, 2016), 16.

7 Joe Moran, Shrinking Violets; Patricia McDaniel, Shrinking Violets and Caspar Milquetoasts: Shyness, Power and Intimacy in the United States, 1950-1995 (New York: New York University Press, 2003); Susie Scott, "The medicalisation of shyness: from social misfits to social fitness". Sociology of Health \& Illness 28, no. 2 (2006): 133-53 and Cristopher Lane, "How shyness became an illness: a brief history of social phobia", Common Knowledge 12, no. 3 (2006): 388-409.
} 
social processes such as medicalisation, psychologisation and pharmaceuticalisation. What feeds the existing historical narratives on shyness is a dissatisfaction with the way shyness and shy people are perceived and treated in our Western society. ${ }^{8}$

Perhaps the fiercest criticism can be found in Christopher Lane's book Shyness: How Normal Behavior Became a Sickness. ${ }^{9}$ In this study, Lane describes how shyness became increasingly pathologised in the West in the course of the second half of the twentieth century. He refers to the role of the American Psychiatric Association subcommittees which were responsible for the revision of the Diagnostic and Statistical Manual for Mental Disorders (DSM). The discussions held in these committees led first of all in 1980 to the inclusion of social phobia - an extreme form of shyness - in the list of potential mental disorders from which people can suffer. Parallel to the introduction of this new disorder, there was also an internal struggle in which proponents of a more neurobiological approach to mental illness wished to do away with more experiential and psychoanalytical approaches. According to Lane, the victory of the neurobiologically oriented approach played into the hands of the many pharmacological firms (such as SmithKline), which were only too happy to capitalise on the tendency to give a physical dimension to social problems.

The English sociologist, Susie Scott, and the American historian, Patricia McDaniel, also pay attention to the medicalisation of shyness in their research into its history. In addition to the biomedical component of this trend, both authors point out that the medicalisation of shyness also takes place in other ways. Scott, for example, argues in her study "The medicalisation of shyness" that the negative and medicalised attitude to shyness cannot be derived solely from the sales figures for certain drugs. ${ }^{10}$ Also, the huge spread of all kinds of psychotherapy in our

\footnotetext{
${ }_{8}$ The exception may be the work of the English linguist, Philippa Lewis: Philippa Lewis, "Twice Shy: Two Accounts of Timidity in fin-de-siècle France", in Medicines and Maladies: Representing Affliction in Nineteenth-Century French Literature, ed. Sophie Leroy (Brill: In press). In this work, Lewis focuses upon the late 19th, early 20th century studies with regard to shyness by the French psychologist Ludovicus Dugas and the German psychiatrist Paul Hartenberg.

${ }_{9}^{9}$ Cristopher Lane. Shyness: How normal behavior became a sickness (Princeton: Yale University Press, 2008).

${ }^{10}$ Scott, "The medicalization".
} 
Western society shows that shyness is seen as an epidemic - as the American shyness specialist Philip Zimbardo put it in the 1970s and 1980s. An army of psychologists stands ready in order to eradicate this epidemic. In addition to the professional counselling of shy people, both Scott and McDaniel also point to the countless self-help books which have been marketed in large numbers since the 1970s. From the study by both authors, shyness emerges as an emotion which is the result both of the structures, (linguistic and empowering material), which surround us as human beings, and of the personal desires and agency of the people themselves.

What unites authors such as Lane, Scott and McDaniel - despite the differences which can be found in the theoretical framework of their studies - is that all three of them mainly focus on what is happening in the second half of the 20th century. In this respect, the book by English cultural historian Joe Moran, Shrinking Violets, stands out. Moran covers a much longer period of time. Rather than looking for cunning and subtle ways to exercise power, Moran also aims to paint a palette of the many (cultural) manifestations of shyness. Through the presentation of well-known and notoriously shy individuals from the 19th and 20th centuries, such as the biologist Charles Darwin, the British singer Stephen Morrissey of The Smiths, the French politician Charles de Gaulle and the British neuropsychiatrist Oliver Sacks, Moran makes a plea for shyness not to be relegated to the dark corners of society: "Shyness isn't what alienates me from the rest of herd-loving humankind; it's the common thread that links me to them". ${ }^{11}$

In addition to the authors mentioned above, there is another important voice in the existing historiography of shyness, namely that of the American cultural historian, Warren Susman. In the book Culture as History: The Transformation of American Society in the Twentieth Centu$r y$, Susman describes the turn of the century around 1900 as a pivotal moment in American history. Between the end of the 19th and the beginning of the 20th centuries, a shift took place from a society which relied mainly on firm and robust characters to one in which it became important to have a personality. This transition from a character culture to a personality culture is cited by several authors as one of the main reasons

11 Joe Moran, Shrinking Violets, 243. 
for understanding the process which led to shyness becoming a problem. ${ }^{12}$ At the end of the 19th century, it became increasingly important for people to try to place themselves on the social map in one way or another. This was due to very different evolutions such as the rise of the consumer society and mass production of cars, for example. The increasing production of cars was one thing. The cars also had to be sold, an activity which greatly benefited the salesman if he was confident, if he did not stutter or tend to look away from the customer, if he was jovial, spontaneous and humorous and above all, if he could win over the hesitant man in front of him with clever arguments and a healthy dose of self-confidence. Whereas a character culture consisted of quiet characters who kept a low profile, a personality culture encouraged people to excel in a particular activity and to display their talents as much as possible. Instead of looking like others in a disciplined way, it became a matter of distinguishing yourself from them. What society needed was not numbers, not endless imitations of the same mother copy, but people who knew how to distinguish themselves from others due to their personality.

According to Susman, this new pattern of expectations with regard to personality led to shy people becoming a problem. In this article, I want to test the hypothesis put forward by Susman that shyness became a problem at the beginning of the 20th century. I will do this by examining, on the one hand, how shyness was dealt with in the reform pedagogics tradition of the time. In doing so, I will focus mainly on Montessori's work. On the other hand, we also want to test Susman's vision against an autobiographical letter from a shy man in the 18th century. On the basis of these two elements, we wish to arrive at a nuanced view with regard to the influence of reform pedagogics upon the Western view of shyness.

\section{SHYNESS AND LES SURVEILLANTS DE SILENCE}

In a number of early twentieth-century texts, silence is cited as an explanatory factor for the emergence of shy characters. A good example can be found in the journal, La Nouvelle Education. The magazine's

\footnotetext{
12 The evolution from a character culture to a personality culture was first described by the American cultural historian Warren Susman: Warren Susman, Culture as History: The Transformation of American Society in the Twentieth Century (New York: Pantheon Books, 1984). ("Personality" and the making of twentieth-century culture, p. 273 onwards).
} 
innovativeness springs immediately to mind from the cover page: "The aim of our association is to bring together all educators in France who are determined to promote the personal activity of children, either at school or in the family". ${ }^{13}$ In line with the reform educational currents which existed at the beginning of the 20th century, La Nouvelle Education focused accordingly upon transforming educational methods in order to promote, stimulate and enable as much as possible the activity of the child. For example, the opening article of the 39th issue of the journal published in 1925 zoomed in on the importance of group work in education. The author of the piece was a certain Gouin, a teacher in the upper years of a primary school in Lamballe/Brittany. From the very start of the piece, he raged against the detrimental effects of studying in silence. The still widespread practice of school students repeating and rehearsing lessons individually and in complete silence did not meet with his approval. The main targets were the invigilators:

The usual attitude of the invigilator of the study is that of a man who wants silence at all costs No whispering, no disruptions! Quiet, the fly which you can hear flying, otherwise, quickly, deep pensive thinking! I know one of these tormentors who does not even admit speech articulated with the lips without sound emission. ${ }^{14}$

Gouin's subsequent sketch of the consequences of the tyrannical silence which prevailed in the study halls of many French schools can be interpreted as a real stepping stone theory. The silent study time ensured that children only counted upon themselves, that they were, or so it seemed, locked up in a cell and showed no inclination to consult anyone else. It was therefore only logical for the author to observe that children became lazy after a while, did not show any curiosity, neglected their tasks and eventually fell prey to silence and shyness.

We lock them up (the children) in their ivory tower, and they are prisoners forever. ${ }^{15}$ Prisoners, exactly, they are silent and shy.

\footnotetext{
13 Anonymous. "Frontispice". La Nouvelle Education 4, no. 39 (1925): 129.

${ }^{14}$ Gouin, G. "Quelques réflexions sur le travail libre par groupes". La Nouvelle Education 4, no. 39 (1925): $127-132$.

15 In the second half of the 20th century, the social psychologist, Phillip Zimbardo, would further develop the metaphorical link between shyness and imprisonment as the very foundation of his psychological ideas about the endemic disease of his time, namely shyness. Zimbardo is best known to
} 
When we question them they remain silent or stammer, ready at once to let others speak ... our pupils have no confidence in themselves ... we are producing by the thousands the seeds from which will be born the innumerable people who will dare to do nothing, shackled in a pusillanimous respect for human nature. ${ }^{16}$

According to Gouin, it was not only children who bore the marks of an overly strict silence at school, but also later, when they reached adulthood, the evidence of this was all too apparent. Countless adults showed the scars of the regime of silence which they had endured during their school days. Just think, says Gouin, of how many adults are forced to disembark at the end of their train or bus journey because they were unable to open the door where they actually wanted to disembark and were too shy to ask fellow passengers for help. And then there were those countless adults for whom public telephone booths were a nightmare.

The telephone box still frightens many city dwellers, even though they may know theoretically how the instruments in that diabolical booth work. But you mustn't ask for anything, or you would look like a fool; and all your life you fail to learn from others, because you were not used to doing so when you were young. ${ }^{17}$

According to Gouin, an incredible amount of people's qualities and competences were wasted in this way, not because they were too vain,

the general public - partly due to the recent book "Most People Are Good" by Rutger Bergman - as the founder of the Stanford Prison Experiment. A number of students were put in the cellars of the university where he taught. The students were divided into a group which had to behave like prisoners and a group which had to behave like guards. The experiment itself soon had to be stopped due to the fact that the group of "guards" became too immersed in their role and there was inhumane treatment of the "prisoners". When discussing the results of this experiment, Zimbardo asked his students whether there were any people who combined the roles of "guard" and "prisoner" within themselves. These discussions made Zimbardo aware of the huge problem caused by shyness. Shy people were both the guards and prisoners of themselves. This issue called for decisive action and, above all, for scientific research. In the course of the 1960s, 1970s and 1980s, Zimbardo (together with his wife) would continue to take an interest in the subject of shyness. He opened clinics for dealing with shyness and published several books on shyness which have been translated into several languages. See, for example, the opening quotation from Philippe Zimbardo \& Robert Norwood, The Silent Prison of Shyness (Standford University, 1974) (Unpublished document): "What other dungeon is so dark as one's own heart! What jailer so inexorable as one's self (Nathaniel Hawthorn)". See also Philippe Zimbardo, Wat is verlegenheid. Wat kan je er tegen doen (Baarn: Ambo, 1977).

${ }^{16}$ G. Gouin, "Quelques réflexions sur le travail libre par groupes", 131.

${ }^{17}$ G. Gouin, "Quelques réflexions sur le travail libre par groupes", 131. 
but because the dominant school culture was a good breeding ground for shy characters. The solution proposed by Gouin involved promoting group work. Rather than letting children get used to working individually, schools should focus upon getting them to work together. The exposure to other people's ideas, the need to search together for a certain answer to a question, the discussion of certain topics would transform the child into a social individual who was not afraid to seek advice from someone else. The oft-quoted counter-argument to group work, that it encourages copycat behaviour, was skilfully undermined by Gouin. The culture of silence which prevailed in so many schools encouraged children to copy, for in order to avoid being punished by the teacher, they made copies of their written and numerical exercises. Here, too, group work could offer a solution, for everyone knew how detrimental copying behaviour was to the stimulation of the intellectual culture.

\section{MARIA MONTESSORI AND SHYNESS AS A MONSTRUOSITY}

Gouin was certainly not the only reform educator who, at the beginning of the 20th century, wrote in a rather negative way about shyness and shy children. Even a writer and educator like Maria Montessori expressed herself in a particularly contemptuous way towards children who behaved in a shy manner. In her most important work, The Montessori Method, she leaves no doubt that for her shyness is a fault, a defect, an abnormality, a disorder, a deficiency:

A natural consequence of this state of affairs (the way in which education and upbringing were shaped) is shyness, a kind of disorder which affects the will, which has not been able to develop - and the consciously or unconsciously violent person takes on this disorder - thus covering up their own mistakes, in the usual tyrannical, slanderous way - as something which is inherent to childhood. Our children are never shy; one of their most attractive qualities is precisely the relaxed manner in which they treat those who work with them in the presence of others, and with which they openly show their work to everyone. The moral monstrosity which we can see in a shy child [...] because it has only been able to develop its will in secret - this monstrosity is not found in "children's homes". Nearly all children in our day and 
age are consequently the victims of a stupid barbarism which behaves towards the will of children in the same way as those criminals who, with all kinds of artifices, manage to turn children's bodies into dwarfs, with ridiculous deformities. At all educational congresses it is recognised that there is a lack of character in schoolchildren: they sound the alarm, but fail to identify the real cause, which is none other than our school discipline, the slavery in schools which breaks down will and character. This is the remedy: people must develop freely. ${ }^{18}$

For Maria Montessori, shyness and timid children are thus the logical consequences of a society in which education is organised in such a way as to frustrate the will of the child. This idea was reinforced at the opening of the first Casa dei bambini. The children cared for there were like "opened flowers, but without the freshness of buds" ${ }^{19}$ They excelled at nothing except moving in a timid and shy manner. However, the lack of expression in their eyes was not something innate. On the contrary. It was the result of the way in which adults set up the world. Whether it concerned the school or the family, in both educational environments Montessori valued the spirit of what she would call in later writings the OMBIUS: "Organisation of evil (Male), which assumes the appearance of good (Bene) and is imposed (Imposto) by the environment on all mankind (Umanita) by means of the Suggestion". ${ }^{20}$ With this acronym, Montessori referred to the practice, which she considered to be widespread, of adults imposing their own will upon that of the child. Whosoever had ever taken the trouble to observe a father or mother walking with a child, would soon become aware of the activity of the OMBIUS forces. Instead of adapting to the will of the child and adjusting the pace of walking accordingly, you will see their fathers and mothers constantly urging the child to walk more quickly. When the child does not respond sufficiently to the request to move forward, it leads quickly to physical force being used, resulting in scenes where a child is violently dragged along. It is

\footnotetext{
18 Maria Montessori, De methode Montessori. Zelfopvoeding van het jonge kind (Amsterdam: Van Holkema \& Warendrof's Uitgevers, 1916), 253 (own emphasis); in the 1950 edition Montessori no longer describes shyness as a monstrosity but speaks of a "moral deformity". Please see Maria Montessori, De Methode. De ontdekking van het kind (Antwerpen: De Sikkel,1950), 343.

19 Maria Montessori, Het geheim van het kinderleven (Antwerpen: De Sikkel, 1937), 154.

${ }_{20}$ Maria Montessori, Het onbegrepen kind (Amsterdam: Van Holkema \& Warendorf, s.d.),70.
} 
important to note that for Montessori this is usually not about ill will. Parents or teachers are often convinced that what they are doing is for the benefit of the child.

Another example to which Montessori often returns in her books is that of the imaginative girl. At one given moment Montessori sees a girl who, with great care and attention, is filling a bucket with sand. She doesn't do it just once, but many times in a row. When the accompanying adult thinks that it is time to go home, she helps the child to fill the bucket of sand for the last time so that the child does not have to stop the activity halfway. The adult's well-intentioned intervention, however, hampers the child's development of her own will because the adult takes over the child's will and, due to time constraints or some other reason, ends the activity in which the child was engaged. Montessori describes this assumption of the child's will by the adults as a suggestion, a term which became increasingly popular at the end of the 19th century, partly as a result of the rise of psychoanalysis. In a way, it was a kind of hypnosis in which one person imposed his or her will on someone else. As a result, the children deviated from the natural developmental path with which they were born. Rather than developing normally, they fell prey to all sorts of childish errors such as mendacity, excessive crying, insomnia, extreme anxiety, capriciousness ... and consequently shyness. As with the other child failings, Montessori saw shyness "as an expression of a subconscious defensive posture in the small child confronted with the superiority of the adult". ${ }^{21}$

Teachers and parents had to become aware of the siren songs that the OMBIUS monster was resonating throughout society. Only then would it be possible to put a stop to the enormous energy being wasted, the untold numbers of children failing to take an active role in their own lives and those of others. Abandoning suggestion and liberating the child would lead to adults who had nothing to hide; to people who could engage with the world with a lively and agile spirit and become the centre of an intense social life. This was the normal situation which Montessori wanted to bring about through a reform of the parenting and educational system.

${ }_{21}$ Maria Montessori, Het geheim van het kinderleven, 143. 


\section{THE SUCCESFUL SELF, THE CULTURE OF PERSONALITY AND THE BATTLE AGAINST SHYNESS}

The reform-oriented criticism of schools and the related plea for the creation of personalities is not only to be found in Montessori's work. In the 1920s, the French reformer, Célestin Freinet, for example, did not have a good word to say about the education system of the time, which in his view was partly responsible for the millions of dead soldiers in the First World War. ${ }^{22}$ Schools, to him, were nothing but military barracks where people were brainwashed into obeying orders without question. It was this educational basis which had led hundreds of thousands of Frenchmen to take up arms spontaneously at the start of the war and to allow themselves to be rushed unceremoniously for 4 years into fighting the German enemy under appalling conditions. If, as Freinet argued, schools had been committed to forming democratic personalities from the end of the 19th century, the powder keg of Europe might never have exploded in 1914. Although Freinet absolutely did not fit the notion of personality into the idea of a capitalist consumer society in which the main objective was to make as much profit as possible in the shortest possible time, we also see the importance of an outspoken personality reflected in his writings.

This is certainly also the case in the work of Ellen Key, the Swedish educator known for her still controversial publication The Century of the Child. Key also left no doubt in her work that she was in favour of reforming schools and the education which they offered to children: "Because from the 2 nd and 3rd year onwards, children are herded together, made to work according to a plan, made to perform the same small, stupid, useless tasks, and it is believed that people are being formed, whereas in reality numbers are being generated". ${ }^{23}$ Instead of having children perform a pre-rehearsed routine, the school should stimulate children's creativity so that they can distinguish themselves from others:

In the excellent modern school, the soft material of individuality is made ready to be used, and this is where the school's success lies - or more precisely, it is swept away in the wind and by

\footnotetext{
22 See for instance: Devos, Jan. De visie van Freinet (Leuven: Garant, 2004).

${ }_{23}$ Key, Ellen. De eeuw van het kind (Zutphen: W.J. Thienen, s.d.), 229.
} 
the waves, just like a small stone on the beach. It is hit by one wave after another, day after day, quarter after quarter. ${ }^{24}$

The landslide which was brought about by the gradual emergence of thinking, speaking and acting in terms of individuality and personality - in the economic sector, but also in the field of parenting and education - helped to make it difficult for shy people to match the ideal of the spontaneous, jovial, and confident man or woman. One of the things from which this can be inferred has to do with the fact that a market arose for books which purported to boost the reader's self-confidence; publications which boasted that after reading the book, the reader's level of aplomb would never reach such known heights; manuals for success and preventing stage fright. ${ }^{25}$ Many of these publications referred to shyness as a deficiency, as a handicap, in short, as something which interfered with someone's personality. His or her shy nature caused the person to fail oral examinations, to misuse his or her goodness, to see the love of his or her life go wrong again and again, or to be persuaded by the first salesman to buy a product which he or she did not need at all.

In a book published in 1908 entitled Comment réussir dans la vie? the author, Jules Fiaux, describes shyness or timidity as a disorder: "What is most damaging to our self-confidence, what opposes it, is fear and shyness. These two shortcomings waste a great deal of our will power, our energy". ${ }^{26}$ According to Fiaux, a flawed education system was at the root of the frequent occurrence of shy characters. The statement on the book's cover made this immediately clear: a well-educated will can control destiny. In the introduction to the book, the author elaborates on his

\footnotetext{
${ }^{24}$ Key, Ellen. De eeuw van het kind, 242.

${ }_{25}$ See among others: W.R. Borg, Les lois éternelles du succès (Avignon: Editions Aubanel Père, 1932); Goh, Clément. Comment guérir les maladies de l'aplomb (Paris: Editions Nilsson, s.d.); Guyot-Daubès L'art de passer avec succès les examens. Examinateurs, l'art de répondre, Fraude et trucs, Les colles! (Paris: Bibliothèque d'éducation attrayante, 1889); Francotte, Xavier. La maîtrise de soi (Bruxelles: Imprimerie médicale et Scientifique, 1911); Jean Leroux, La timidité n'existe plus!!! Celui qui nous lit peut la vaincre!!! Une revolution dans le théâtre, dans l'amour, dans les arts, dans la vie (Paris: Union de la Presse, s.d.); Louis Nicolas Bescherelle, L'art de briller en société et de se conduire dans toutes les circonstances de la vie (Paris: Imprimerie Schneider, s.d.); S. Roudès, Pour faire son chemin dans la vie. Moyens et qualité qui permettent d'arriver au succès et à la fortune (Paris: Bibliothèque des ouvrages pratique, s.d.); In the book La sociabilité et le monde by Charles Bigot published in 1895 shyness is described as "one of the greatest sufferings which men living in society can endure": Charles Bigot, La sociability et le monde (Paris: Charles Bérissey, 1895), 161.
}

26 Jean Fiaux, Comment réussir dans la vie? (Paris: H. Daragon, 1908), 26. 
train of thought. According to him, there are two types of education: the education which we receive from others and the education with which we provide ourselves. The education which we receive from others - at school, for example - is incredibly inadequate because it saps our energy, and we learn above all to depend upon others. As a result, when we are finished with school, we are easy prey for newspaper editors, job managers, politicians and salesmen. You don't have a backbone nor your own opinion and so you are like a bird facing a cat when confronted with people who are trying to win others over. The dependency which results from mainstream education needs to be corrected so that the individual can learn to trust in himself and his own will.

A few years after Fiaux's publication, another book on how to become self-confident appeared on the market. Again, shy people are described as a problem, but the language used is much more belligerent. The author, a certain Dr. Starke, declares war upon shyness: "guerre à la timidité". In his opinion, shy people lead a miserable existence. They are slow to understand, insecure, and totally unwilling to take any action in their lives: "(Shy people) prefer to hide in the caves on the shore, rather than attempt a successful crossing". ${ }^{27}$ Those who are shy show many of the characteristics of paralysed individuals: "like the latter, they have organs which do them no service and their usual lack of functioning ends up by ankylosing them in a definitive way" ${ }^{28}$ Shy people are not in a position to participate in an active life. They cannot reason or judge, they often have poor health, they suffer from turning red, they stutter, they are indecisive, and they are afraid of making mistakes. In fact, according to the author, they most resemble children who run around in all different directions.

The inferiority of the shy individual is then once again made clear by the author by using a metaphor based upon traffic. When confronted with a busy street, a shy person will stay at the edge of the road. He will not dare to cross the road. A self-confident person will have no problem with that at all. "He knows exactly where he wants to go and where he can go; so we see him walking without any hesitation, with

\footnotetext{
${ }^{27}$ D. Starke, L'aplomb (Paris: Editions Nilsson, 1913), 27; the book was part of a series where the other issues in the series had titles such as La persévérance, l'esprit d'à-propos and La force de caractère.

${ }_{28}$ D. Starke, L'aplomb, p. 29.
} 
his eyes fixed upon the goal which he covets". ${ }^{29}$ Although it is tempting to link the turning of shyness into a problem with the transition from a 19 th century character culture to a 20th century personality culture, the opening sentence of the book, L'aplomb, suggests that this view is not entirely correct: "lack of confidence has always been a hindrance to those who are haunted by the desire to be successful. In every age, the awkwardness which arises from shyness has been detrimental to those who suffer from it. But this flaw has never been more noticeable than in contemporary society". 30

Shyness, according to Dr Starke, was more prevalent than ever in a wide range of social contexts. ${ }^{31}$ A remarkable example of this can be found in the journal La soierie de Lyon: Revue Technique des industries de la soie from 1933. In one of the articles, the author looked at the problem of shyness in sales. The opening line of the piece left no doubt. There was a problem because $70 \%$ of people were afraid to enter a shop. The cause, according to a certain Dr Toulouse, was shyness: "My bookseller told me that the great hindrance to sales is shyness. Out of ten people whom you see examining the books on the stalls outside, there are not three who would dare step inside without having a very definite idea of a purchase to be made". ${ }^{32}$ The ultimate solution to this problem, and therefore the ideal way to boost sales, was to invest in the shop window. Window-dressing was the sales industry's answer par excellence to the huge prevalence of shy individuals: "the shy man looks at window displays and examines the detail: he can make his choice in all peacefulness ... he is fond of shop windows". ${ }^{33}$

\footnotetext{
29 D. Starke, L'aplomb, p. 36.

30 D. Starke, L'aplomb, p. 5.

${ }^{31}$ For a series of articles on shyness and stage fright in the theatre world by Gratia, please see L.E. Gratia, "Le trac et la timidité". Le Menestrel. Musique et Théatres 94, no. Vendredi 14 Octobre, Vendredi 21 Octobre \& Vendredi 28 Octobre (1932); for a brief discussion of how dance can be a resource for curing shyness: G. Appolinaire, "La danse est un sport". La Culture Physique; Revue bi-mensuel e illustrée de tous les sports 4, no. 50 (1907) : 62-68.; Please see also Paul Voivenel, "Sur la timidité et le trac". L'Archer 5 (1930): 399-431; The topic of shyness was also widely discussed in the press at the time. Please see for example the literary supplement of the French newspaper Le Figaro from 1893 (19th edition, Saturday 2 December, p. 191).

32 H. Gleveo, "L'étalage moderne". La Soierie de Lyon. Revue Technique des Industries de la Soie 6, no. 6 (1933): 122-128.

${ }_{33}$ H. Gleveo, "L'étalage moderne", p. 127.
} 


\section{A CERTAIN TIMIDUS FROM THE 18TH CENTURY: PAPER CAN'T BLUSH}

It is clear that shy people at the beginning of the 20th century faced a number of social changes which made their shyness increasingly a problem. The reform pedagogical ideas and practices concerning the self, the personality and the adoption of an active attitude certainly contributed to this. However, one should not conclude from this that shyness did not exist in earlier times, let alone that it did not pose any problem to those whose behaviour was characterised by it. For example, in the year 1772 two fascinating articles about shyness appeared in the 18th century Dutch journal De onderzoeker. Both the authors described shyness as a problem.

In the first article, which went to press on 6 January 1772, the anonymous author starts with the observation that there are people who are incredibly talented but are overcome by a self-conscious shyness when surrounded by company. It describes shyness as an "intrinsic disorder" and does so in three respects. ${ }^{34}$ First and foremost shyness prevents people from enjoying company. For the shy individual, being together with others is akin to being on a rack - both mentally and physically. The defective nature of shyness is not only related to a fear of company. It is also associated with the prejudices linked to the fact that people do not dare to talk in public: "The man will not speak", according to the writer, "so he doesn't know what to say, so he's a nitwit, a fool". ${ }^{35}$ Shy people, according to this writer, were apparently lumped together with madmen and lunatics precisely because they kept silent or because they expressed themselves in such a way that what they said was considered to be a rant. A third way in which shyness caused a person to fail, according to the author, was that it prevented a man or woman from undertaking certain things. Shy people, for example, did not dare to ask someone to marry them. The author of the article attributes the cause of shyness to a badly flawed upbringing which results in a "lack of worldliness". ${ }^{36}$ Many shy people come from a family in which the children were constantly reprimanded, criticised and censured. Or they were children whose parents

\footnotetext{
34 Anonymous. “Over de beschroomdheid”. De onderzoeker 4, no. 167 (1772), 83.

35 Anonymous. "Over de beschroomdheid”, 83.

36 Anonymous. "Over de beschroomdheid", 85.
} 
were incredibly protective and who locked their offspring up in a room or shielded them from contact with other people. It should therefore not surprise anyone, he said, that these children considered other people to be "terrible creatures".

A few months later, in May 1772, De Onderzoeker published an autobiographical text by a man who was incredibly grateful to the author of the article concerning shyness. The article was signed by a certain Timidus, a 40-year-old man who had recognised himself in an incredible way in the text about shyness. Over the years, he had become convinced that he was a fool, and that others viewed him in exactly the same way. ${ }^{37}$ The text from De Onderzoeker had pointed out to him that he was not a fool at all, that his behaviour was not due to a lack of certain abilities but was the result of a profound shyness. In the text, Timidus stated that he was giving an account of his condition and his life for the first time, something he had never dared to do in a verbal conversation with someone before, "because if I have to say more than 'yes' or 'no', I will get colour behind my ears. But paper cannot blush". ${ }^{38}$ Timidus came from a wealthy background. His parents possessed a considerable amount of capital and were very strict in their upbringing: "for the slightest mistake, I was yelled at, beaten or locked up". ${ }^{39}$ Whether he said something or was quiet, he was constantly reprimanded: "first I was sitting crookedly on my chair, then I was stooping too much, then I was holding my shoulders too high; at other times I had to stand up when I was sitting down, or to sit down when I was standing up". ${ }^{40}$ His parents did not allow him to go to school because there he would only come into contact with evil things, so Timidus was entrusted to a private teacher. At the age of 20, his parents sent him anyway to the Academy. Like other boys his age, he ended up at a hospice. His fellow students soon realised that Timidus could be pushed around and 20 to 30 of them gathered around him "like a madman, a strange beast or a drunken man". ${ }^{41}$ In an attempt to rid himself of his tormentors, Timidus locked himself in his room,

\footnotetext{
37 Timidus. "Brief van Timidus over zyne beschroomdheid”. De onderzoeker 4 no. 186 (1772): $233-240$.

38 Timidus. "Brief van Timidus over zyne beschroomdheid", 234.

39 Timidus. "Brief van Timidus over zyne beschroomdheid”, 235.

40 Timidus. "Brief van Timidus over zyne beschroomdheid”, 235.

41 Timidus. "Brief van Timidus over zyne beschroomdheid”, 236.
} 
but even there he was not safe. Some 8 to 9 tormentors came around to rag him. He tried to placate them by pouring them wine at will. It was all to no avail. On the contrary, the drink made the boys lusty and at one point they dragged him out by his hair while shouting, "He should be used for making noodles". Timidus then concludes his autobiographical text with an appeal to fathers and mothers to "take care of their children, not to repress them when they are young and thus extinguish the spirit in them". ${ }^{42}$

In the 18 th century text by Timidus, shyness is clearly described as a problem. It is something which makes a person feel uncomfortable, and which makes them feel different from others. However, the sources mentioning shyness at the end of the 18th century and the beginning of the 19th century also present another picture. One in which shyness was highlighted as a positive and laudable human trait. In 1828, for example, an anonymous author contrasted shyness with frivolity. This latter characteristic symbolises a certain emptiness, a shortage of ideas and superficiality. Those who are shy, on the other hand, have much to offer. It involves someone who can be counted upon. "In childhood, shyness always indicates a good nature. He who doubts nothing, has nothing indeed in his soul and suspects nothing". ${ }^{43}$ The same positive attitude towards shyness can be found in the play "On being disgusted with bashfulness in boys" by the English author Vicesimus Knox published in 1823. Knox uses a metaphor from nature to make his point. He refers to a young bird which only leaves the nest when its feathers are sufficiently developed, as well as to the bud of a flower which only unfolds when it is sufficiently developed. Something similar, says Vicesimus Knox, takes place in the development of children. "Yet, it is stigmatized with the odious name of shyness and sheepishness, and many parents appear more solicitous to divest their children of it, than to furnish them with any grace, virtue, or accomplishment". ${ }^{44}$ This stigmatisation of a perfectly normal fact is incomprehensible to Knox, all the more so because shyness is an important stage in human development: "All who

\footnotetext{
42 Timidus. "Brief van Timidus over zyne beschroomdheid", 240.

43 Anonymous. "La timidité". Le Lycée Armoricain 12, no. 70 (1828): 235-238.

${ }^{44}$ Vicesimus Knox, Winter evenings: or, lucubrations on life and letters (London: J. Richardson \& Co, 1823), 140.
} 
are to excel in the future, must devote a previous time to discipline. He who would one day speak, must first listen" ${ }^{45}$ The tendency of parents to let their children just not be shy results in that "we commonly meet with forward young men, who overpower all around them with noise, who are incapable of rational conversation, who are avoided by all sensible persons, and who associate with the only characters who can enjoy their company, gamesters, horse-jockeys, phaeton-drivers, drunkards, and debauchees" ${ }^{46}$

Despite the fact that a number of authors described shyness as a praiseworthy character trait which should certainly be respected during childhood, there were certainly also voices describing shyness as a problem. An example of this can be found in the early 19th century letters from Earl Chesterfield to his son. For the father, modesty was an incredibly beautiful virtue. Men who issued commands always and everywhere and constantly sang their own praises could not be trusted. At the same time, the father urged his son not to develop a shy character. This "awkward bashfulness" was something to be avoided at all costs, because

One ought to know how to come into a room, speak to people, and answer them, without being out of countenance, or without embarrassment ... a gentleman, who is used to the world, comes into company with a graceful and proper assurance, speaks even to people he does not know without embarrassment, and in a natural and easy manner. This is called usage of the world, and good breeding. ${ }^{47}$

\section{CONCLUSIONS}

Shyness and being shy is a problem for many people today. Both schoolchildren and adults are expected to be extroverted, spontaneous, self-confident and not afraid to speak in front of an audience. The existing

\footnotetext{
45 Vicesimus Knox, Winter evenings, p. 141.

46 Vicesimus Knox, Winter evenings, p. 143.

47 George Gregory, The elements of a polite education; carefully selected from the letters of the late Earl of Chesterfield to his son (London: Richard Phillips, s.d.), 15-16; also published in 1815 was an essay on shyness by Samuel Chalmers. In this essay, the positive and negative sides of shyness are juxtaposed in a rather chaotic manner - which earned the author a swipe at him by a critic at the time, who was particularly critical of the text's incoherent nature. S. Chalmers, S. An essay on bashfulness (Hawick: Robert Armstrong, 1815).
} 
histories of shyness mainly point to the turning of shyness into a medical condition during the second half of the twentieth century as a result of the rise of psychopharmaceuticals, the emergence of a service society and a wider tendency to turn undesirable behaviours and feelings into a medical condition. Some writers, such as the American cultural historian, Warren Susman, have also pointed to the impact of the social changes which took place around 1900 when the United States switched from being a character-based society to a personality-based society. In this article, we have looked at how shyness was addressed in the work of Maria Montessori. Montessori's negative view of shyness fits in with the attention paid by the reform pedagogics of the time to active teaching formats, such as project work. But it is also very much in line with the demands of the reform educators of the time for the formation of personalities and for the child to educate itself. Accordingly, also within the school context around 1900, we find indications that the personality culture - as it was expressed within reform pedagogics - cast shyness in a bad light and made it a problem. However, this in no way means that shy people did not struggle with feelings of shyness before the 20th century. The autobiographical letter from the year 1772, which appeared in the Dutch Enlightenment journal De Onderzoeker, showed like no other how the 40-year-old Timidus was tormented by his shyness. What the reform pedagogics definition of shyness as a problem does show is that around 1900 learning processes and educational practices were increasingly used to solve the problem of shyness. The self-help books which appeared on the book market at the beginning of the 20th century also endorse this tendency to turn shyness into an educational concept.

\section{Note on the author}

Pieter Verstraete is associate professor history of education at the research centre for Education, Culture and Society of the KU Leuven. Since 2020 he is president of the Belgian-Dutch Society for the History of Education. He is also curator of the annual Leuven Disability Filmfestival. In his current book project he concentrates on the history of silence in the classroom - Shhht! A history of the modern school (to be published in 2022 by Leuven University Press). 


\section{REFERENCES}

Anonymous. “Over de beschroomdheid”. De onderzoeker 4, no. 167 (1772): 81-88. Anonymous. "La timidité”. Le Lycée Armoricain 12, no. 70 (1828): 235-238.

Anonymous. "Frontispice”. La Nouvelle Education 4, no. 39 (1925): 129.

Appolinaire, G. "La danse est un sport”. La Culture Physique; Revue bi-mensuel e illustrée de tous les sports 4, no. 50 (1907): 62-68.

Bescherelle, Louis Nicolas. L'art de briller en société et de se conduire dans toutes les circonstances de la vie. Paris: Imprimerie Schneider, s.d.

Bigot, Charles. La sociability et le monde. Paris: Charles Bérissey, 1895.

Boler, Megan. Feeling power: Emotions and education. New York: Routledge, 2004.

Borg, W.R. Les lois éternelles du succès. Avignon: Editions Aubanel Père, 1932.

Chalmers, S. An essay on bashfulness. Hawick: Robert Armstrong, 1815.

Deluermoz, Quentin, Emmanuel Fureix, and Hervé Mazurel. "Écrire l'histoire des émotions: de l'objet à la catégorie d'analyse". Revue d'histoire du XIXe siècle. Société d'histoire de la révolution de 1848 et des révolutions du XIXe siècle 47 (2013): 155-89.

Devos, Jan. De visie van Freinet. Leuven: Garant, 2004.

Fiaux, Jean. Comment réussir dans la vie? Paris: H. Daragon, 1908.

Francotte, Xavier. La maîtrise de soi. Bruxelles: Imprimerie médicale et Scientifique, 1911.

Gleveo, H. "L'étalage moderne”. La Soierie de Lyon. Revue Technique des Industries de la Soie 6, no. 6 (1933): 122-128.

Goh, Clément. Comment guérir les maladies de l'aplomb. Paris: Editions Nilsson, S.d.

Gouin, G. "Quelques réflexions sur le travail libre par groupes". La Nouvelle Education 4, no. 39 (1925): 127-132.

Gratia, L.E. "Le trac et la timidité". Le Menestrel. Musique et Théatres 94, no. Vendredi 14 Octobre, Vendredi 21 Octobre \& Vendredi 28 Octobre (1932).

Gregory, George. The elements of a polite education; carefully selected from the letters of the late Earl of Chesterfield to his son. London: Richard Phillips, S.d.

Guyot-Daubès L'art de passer avec succès les examens. Examinateurs, l'art de répondre, Fraude et trucs, Les colles! Paris: Bibliothèque d'éducation attrayante, 1889.

Key, Ellen. De eeuw van het kind. Zutphen: W.J. Thienen, S.d.

Knox, Vicesimus. Winter evenings: or, lucubrations on life and letters. London: J. Richardson \& Co, 1823.

Lane, Cristopher "How shyness became an illness: a brief history of social phobia”, Common Knowledge 12, no. 3 (2006): 388-409.

Lane, Cristopher. Shyness: How normal behavior became a sickness. Princeton: Yale University Press, 2008. 
Leroux, Jean. La timidité n'existe plus!!! Celui qui nous lit peut la vaincre!!! Une revolution dans le théâtre, dans l'amour, dans les arts, dans la vie. Paris: Union de la Presse, S.d.

Lewis, Philippa. "Twice Shy: Two Accounts of Timidity in fin-de-siècle France”. In Medicines and Maladies: Representing Affliction in Nineteenth-Century French Literature. Editado por Sophie Leroy. Brill: In press.

Malfait, Catherine \& Jeannin, Niki. Emoties in de kleuterklas. Oefenen met de methode van "Het Toverbos". Tielt: Lannoo Campus, 2014.

McDaniel, Patricia. Shrinking Violets and Caspar Milquetoasts: Shyness, Power and Intimacy in the United States, 1950-1995. New York: New York University Press, 2003.

Montessori, Maria. De methode Montessori. Zelfopvoeding van het jonge kind. Amsterdam: Van Holkema \& Warendrof's Uitgevers, 1916.

Montessori, Maria. Het geheim van het kinderleven. Antwerpen: De Sikkel, 1937.

Montessori, Maria. De Methode. De ontdekking van het kind. Antwerpen: De Sikkel, 1950.

Montessori, Maria. Het onbegrepen kind. Amsterdam: Van Holkema \& Warendorf, S.d.

Moran, Joe. Shrinking Violets: The Secret Life of Shyness. London: Profile Books, 2016.

Plamper, Jan. Geschichte und Gefühl: Grundlagen der Emotionsgeschichte. München : Siedler Verlag, 2012.

Roudès, S. pour faire son chemin dans la vie. Moyens et qualité qui permettent d'arriver au succès et à la fortune. Paris: Bibliothèque des ouvrages pratique, S.d.

Scott, Susie. "The medicalisation of shyness: from social misfits to social fitness". Sociology of Health \& Illness 28, no. 2 (2006): 133-53.

Sobe, Noah. "Researching emotion and affect in the history of education". History of Education 41, no. 5 (2012): 689-95.

Starke, D. L'aplomb. Paris: Editions Nilsson, 1913.

Stearns, Peter and Clio Stearns. "American schools and the uses of shame: an ambiguous history”. History of Education 46, no. 1 (2017): 58-75.

Susman, Warren. Culture as History: The Transformation of American. Society in the Twentieth Century. New York: Pantheon Books, 1984.

Timidus. "Brief van Timidus over zyne beschroomdheid". De onderzoeker 4 no. 186 (1772): 233-240.

Toohey, Peter, Verveling: een boeiende geschiedenis. Amsterdam: Ambo/Contact, 2012.

Verstraete, Pieter. "Het verlegen kind. Een pedagogische kijk op de geschiedenis van emoties". In Images of education: cultuuroverdracht in historisch perspectief. Edited by Hilda Amsing, Nelleke Bakker, Minneke van Essen \& Sanne Parlevliet, 235-247. Groningen: Uitgeverij Passage, 2018. 
Voivenel, Paul. "Sur la timidité et le trac". L'Archer 5 (1930): 399-431.

Zimbardo, Philippe. Wat is verlegenheid. Wat kan je er tegen doen. Baarn: Ambo, 1977.

Zimbardo, Philippe \& Norwood, Robert. The silent prison of shyness. Standford University, 1974 (Unpublished document). 